\title{
Glucagon-like peptide-1 attenuated carboxymethyl lysine induced neuronal apoptosis via peroxisome proliferation activated receptor- $\gamma$
}

\author{
Haoqiang Zhang ${ }^{1,2}$, Bing Song ${ }^{3}$, Wenwen Zhu ${ }^{1,2}$, Lili Liü ${ }^{3}$ Xiqiao $\mathrm{He}^{3}$, Zheng Wang ${ }^{1,2}, \mathrm{Ke} \mathrm{An}^{1,2}$, \\ Wuyou Cao ${ }^{1,2}$, Jijing Shi ${ }^{1,2}$, Shaohua Wang ${ }^{1,2}$ \\ ${ }^{1}$ Department of Endocrinology, Affiliated Zhongda Hospital of Southeast University, Nanjing 210000, Jiangsu \\ Province, China \\ ${ }^{2}$ School of Medicine, Southeast University, Nanjing 210000, Jiangsu Province, China \\ ${ }^{3}$ Department of Endocrinology, First Affiliated Hospital of Jinzhou Medical University, Jinzhou 1210001, Liaoning \\ Province, China
}

Correspondence to: Shaohua Wang; email: gyjwsh@126.com, https://orcid.org/0000-0001-9567-6668

Keywords: carboxymethyl-lysine, apoptosis, glucagon-like peptide-1, peroxisome proliferator activated receptor- $\gamma$

Received: October 28, $2020 \quad$ Accepted: July 8, $2021 \quad$ Published: July 29, 2021

Copyright: (c) 2021 Zhang et al. This is an open access article distributed under the terms of the Creative Commons Attribution License (CC BY 3.0), which permits unrestricted use, distribution, and reproduction in any medium, provided the original author and source are credited.

\section{ABSTRACT}

Backgrounds and aims: The role of peroxisome proliferator activated receptor- $\gamma$ (PPAR- $\gamma$ ) in neuronal apoptosis remains unclear. We aim to investigate the role of PPAR- $\gamma$ in glucagon-like peptide-1 (GLP-1) alleviated neuronal apoptosis induced by carboxymethyl-lysine (CML).

Materials and Methods: In vitro, PC12 cells were treated by CML/GLP-1. Moreover. the function of PPAR- $\boldsymbol{\gamma}$ was blocked by GW9662. In vivo, streptozotocin (STZ) was used to induce diabetic rats with neuronal apoptosis. The cognitive function of rats was observed by Morris water maze. Apoptosis was detected by TUNEL assay. Bcl2, Bax, PPAR- $\gamma$ and receptor of GLP-1 (GLP-1R) were measured by western blotting or immunofluorescence.

Results: In vitro experiment, CML triggered apoptosis, down-regulated GLP-1R and PPAR-ү. Moreover, GLP-1 not only alleviated the apoptosis, but also increased levels of PPAR- - . GW9662 abolished the neuroprotective effect of GLP-1 on PC12 cells from apoptosis. Furthermore, GLP-1R promoter sequences were detected in the PPAR- $\nu$ antibody pulled mixture. GPL-1 levels decreased, while CML levels increased in diabetic rats, compared with control rats. Additionally, we observed elevated bax, decreased bc12, GLP-1R and PPAR- $\gamma$ in diabetic rats.

Conclusions: GLP-1 could attenuate neuronal apoptosis induced by CML. Additionally, PPAR- $\gamma$ involves in this process.

\section{INTRODUCTION}

Prevalence of type 2 diabetes (T2DM) [1-4] and Alzheimer's Disease (AD) $[5,6]$ had been a challenge in China and worldwide. T2DM is involved in the progress of $\mathrm{AD}$ via several mechanisms, including amyloid- $\beta$ accumulation $[7,8]$, hyperphosphorylation of tau protein $[9,10]$ and oxidative stress [11] result in neuronal apoptosis [12]. Advanced glycation end products (AGEs), formed by non-enzymatic-reaction in the condition of chronic hyperglycemia, are involved in various diabetic complications, including degenerative neuropathy. Indeed, many studies suggested that AGEs promoted the damage of neurons by binding to receptor of advanced glycation end products (RAGE). Chen et al. [13] showed high glucose induced apoptosis by PC12 cells in vitro and STZ induced hyperphosphorylation of tau protein by rats in vivo. Additionally, recent study [12] indicated that induced neuronal apoptosis in SH-SY5Y cells. However, the mechanism of AGEs involves in neuronal apoptosis needs to be further studied.

GLP-1 is a kind of incretin mainly secreted by intestinal $\mathrm{L}$ cells, open-type intestinal epithelial endocrine cells 
located in the distal ileum and colon [14]. It could bind to GLP-1R, and then, maintain plasma glucose stabilization via the balance of insulin and glucagon [15]. GLP-1R is a member of $\mathrm{G}$ protein-coupled receptor [16], expression in the heart, pancreatic, stomach, intestine, lung, kidney, gut nerve and brain [17]. Wei et al reported the expression of GLP-1R in brain firstly and indicated that GLP-1R in brain, heart and pancreatic have the same deduced amino acid sequences [18]. Although most GLP-1 was secreted by $\mathrm{L}$ cells is inactivated soon (within 2 minutes) by dipeptidyl peptidase 4 (DPP-4), study showed that microglial cells [19] as well as a cluster of neurons in the nucleus of the solitary tract and a smaller number of neurons that extend laterally from the nucleus of the solitary tract [20] could secrete GLP-1. This kind of GLP-1 may bind to the GLP-1R in the brain, and then trigger neuroprotective effect.

Recent studies showed neuroprotective effect of GLP1 (or GLP-1 analogue) and its receptor [21, 22]. Kappe et al. found GLP-1 decreased in ob/ob mice with cognition declines [19]. Moreover, Liraglutide administration could improve the cognitive function of mice [23, 24]. GLP-1R-deficient mice have a phenotype characterized by a learning deficit that is restored after hippocampus GLP-1R gene transfers. However, rats over-expressing GLP-1R in the hippocampus show improved learning and memory [25]. Additionally, GLP-1 attenuates AGEs-induced RAGE up-regulation in SH-SY5Y cells and improved the AGEs-induced cells vitality declines [12].

PPAR- $\gamma$ is not only a potential target to treat diabetes by alleviating insulin resistance [26], but also play a promising role in neuroprotective effect $[27,28]$. In recent studies, researchers demonstrated that PPAR- $\gamma$ may contribute to prevent apoptosis from AGEs and oxidative stress $[29,30]$. However, the role of PPAR$\gamma$ in the process of RAGE medicated neuronal apoptosis is still unclear. In another work, PPAR- $\gamma$ was upregulated by the administration of GLP-1 [31, 32]. But, thus far, the relationship between GLP-1R and PPAR $-\gamma$ remains need to be further explored in PC12 cells.

CML, is one of the most studied components of AGEs [33]. It could induce damage and apoptosis of podocyte [34], foam cells [35] and neurons [36]. In addition, GLP-1 showed its anti-apoptosis in many different cell types [37]. Although, PPAR- $\gamma$, associated with apoptosis [29], is regulated by GLP-1 [31], the mechanism of GLP-1 alleviated apoptosis of PC12 cells induced by CML is still unclear. So, we designed this study to explore the role of PPAR $-\gamma$ in GLP-1 alleviated apoptosis induced by CML in PC12 cells.

\section{MATERIALS AND METHODS}

\section{Cell culture and differentiation}

PC12 cell line was purchased from American Type Culture Collection and stimulated to form a neuron-like phenotype [38, 39] with nerve growth factor (Novoprotein, Shanghai, China, Catalogue No.: C060) $(50 \mathrm{ng} / \mathrm{ml})$ for 3 days. And then, they were cultured in Dulbecco's modified eagle's medium (DMEM) (Gibco by Thermo Fisher Scientific TM, Suchoo, China) supplemented with 5\% fetal bovine serum (FBS) (Gibco, Australia, Catalogue No.: A3161001C), 1\% penicillin/streptomycin (Beyotime, Shanghai, China, Catalogue No.: C0222) and $10 \%$ horse serum (Beyotime, Shanghai, China, Catalogue No.: C0262). Cells were harvested for passaging when plates were $90 \%$ confluent.

\section{CML stimulating, GLP-1 treatment and GW9662 blocking assay}

For CML (MyBioSource, San Diego, USA, Catalogue No.: MBS390113) stimulating, cells $(5 \times 103)$ in $100 \mu 1$ DMEM were added to 96-well plates with different concentrations of $\mathrm{CML}(0,12.5,25,50,75$, and $100 \mu \mathrm{g} / \mathrm{ml}$ ) for 6,12 and 24 hours. GLP-1 (Bioss, Beijing, China, Catalogue No.: bs-0038P) treatment was performed with GLP-1 at concentrations of $0 \mathrm{nM}, 50 \mathrm{nM}$, $100 \mathrm{nM}, 200 \mathrm{nM}$, and $500 \mathrm{nM}$ in the medium with cells stimulated by $50 \mu \mathrm{g} / \mathrm{ml} \mathrm{CML}$ for 24 hours. GW9662 (MedChemExpress LLC, Shanghai, China, Catalogue No.: 22978-25-2) blocking administration was conducted by $0,1,5,10,20$, and $50 \mu \mathrm{M}$ GW9662 in PC12 cells with $50 \mu \mathrm{g} / \mathrm{ml} \mathrm{CML} \mathrm{and} \mathrm{100nM} \mathrm{GLP-1} \mathrm{for}$ 24 hours. After CML stimulating, GLP-1 treatment and GW9662 blocking assay, CCK-8 assay was performed according to the protocol of manufacturer (Jiangsu KeyGEN BioTECH Corp., Ltd, Nanjing, China, Catalogue No.: KGA317-2).

\section{Animal housing and treatment}

Adult male Wistar rats (6 weeks old) were purchased from Beijing HFK Biotechnology Co., Ltd. (Beijing, China) and housed in a specific pathogen-free animal center. All rats were fed with their specific diet and bacteria free water. To get hyperglycemia models, they were induced by STZ (Sigma-Aldrich, Saint Louis, MO, USA, Catalogue No.: V900890) (a single dose intraperitoneal $60 \mathrm{mg} / \mathrm{kg}$ ) prepared in in a $0.1 \mathrm{M}$ citrate buffer ( $\mathrm{pH} 4.5$ ) after 12 hours fasting. After 72 hours injections, fasting blood glucose $>16.7 \mathrm{mmol} / \mathrm{L}$ was admitted as diabetes. 8 diabetic rats and 8 control rats were divided into diabetic rat group and control rat group respectively. This present study was approved by 
the Animal Studies Committee of our institution and conducted in accordance with the Guide for the Care and Use of Laboratory Animals.

\section{Morris water maze}

After a period of 8 weeks from the success of the diabetic models, Morris water maze tests were conducted to detect the cognitive function. Before training, rats were allowed to swim freely to adapt the environment for $1 \mathrm{~min}$ without the platform. Then, each rat was trained for five consecutive days to find the platform. The time of each rat took to find the platform and the total length of the path were recorded as escape latency and path length respectively. Additionally, we also recorded the percentage of time spent in the target quadrant as well as the frequency of crossing the platform area.

\section{TUNEL assay}

TUNEL kit (Servicebio, Wuhan, China, Catalogue No.: G1507-50T) were used to measure levels of apoptosis according to the manufacturer's protocol.

\section{Western blotting}

After CCK-8 test, CML $(50 \mu \mathrm{g} / \mathrm{ml})$ was selected to induce PC12 cells apoptosis for 24 hours. Additionally, GLP-1 (100nM) was used to treatment CML induced cells damage. Moreover, GW9662 at a concentration of $5 \mu \mathrm{M}$ was administrated to inhibit PPAR- $\gamma$. Western blotting was carried out according to a previously described protocol [40]. Briefly, total proteins from tissue or cells were extracted using radioimmunoprecipitation (RIPA) (Wanlei Biotechnology Co. Ltd, Shenyang, China, Catalogue No.: WLA016a) with 1\% phenylmethanesulfonyl fluoride added. Subsequently, a BCA protein assays kit (Wanlei Biotechnology Co. Ltd, Shenyang, China, Catalogue No.: WLA004b) was used to measure protein concentration according to the manufacturer's protocol. Proteins were separated in SDS-PAGE gels (10\%) and transferred to polyvinylidene fluoride membranes (Merck KGaA, Darmstadt, Germany). Rabbit-anti-rat primary antibodies were used to bind target proteins including bax (Wanlei Biotechnology Co. Ltd, Shenyang, China, Catalogue No.: WL01637), bcl2 (Wanlei Biotechnology Co. Ltd, Shenyang, China, Catalogue No.: WL01556), GLP-1R (Bioss, Beijing, China, Catalogue No.: bs-1559R), and PPAR- $\gamma$ (Santa Cruz Biotechnology, Inc., Dallas, TX, USA, Catalogue No.: sc-390740) at $4^{\circ} \mathrm{C}$ overnight. Following, HRP conjugated goat-anti-rabbit secondary antibody (Wanlei Biotechnology Co. Ltd, Shenyang, China,
Catalogue No.: WLA023a) incubation administration was performed to detect primary antibodies. Revelation of proteins realized by ECL kit (Wanlei Biotechnology Co. Ltd, Shenyang, China, Catalogue No.: WLA006a).

\section{Chromatin immunoprecipitation (ChIP)}

The ChIP assay was conducted according to the protocol from the manufacturer (Wanlei Biotechnology Co. Ltd, Shenyang, China, Catalogue No.: WLA122). PC12 cells were cross-linked by $1 \%$ formaldehyde (10 min at room temperature) before ultrasonic splintering. Chromatin solutions were incubated with $4 \mu \mathrm{g}$ of antiPPAR- $\gamma$ antibody or with IgG, and rotated overnight at $4^{\circ}$ C. Complexes were collected with protein A Sepharose beads for 1 hour at $4^{\circ} \mathrm{C}$. To purify the immunoprecipitated DNA, beads were treated with DNase-free RNase A and proteinase K. And then, DNA was resuspended by distilled water. To amplify the GLP-1R promoter regions containing PPAR- $\gamma$, 5'-CAAGTCCACGCTGACACTC-3' and 5'-GCTCTG TAAACAGCTTGATGAA-3' were used as forward and reverse primers respectively [41]. After amplification, PCR products were analyzed on a $2 \%$ agarose gel. For quantification of the ChIP assay, input genomic DNA and immunoprecipitated DNA were amplified by realtime PCR.

\section{Plasmatic concentration of GLP-1 and CML measurements}

All rats were anesthetized by $4 \%$ halothane anesthesia and sacrificed after the cognitive function tests. Fasting blood samples and fresh brain tissue were collected for further research. Blood samples $(50 \mu l)$ were collected from rats' angular veins after fasting for 8 hours. Plasmatic GLP-1 (CUSABIO, Wuhan, China, Catalogue No.: CSB-E08117r) and CML (LifeSpan BioSciences, Seattle, WA, USA, Catalogue No.: LS-F27924) levels were measured by ELISA according to the Manufacturer's instructions.

\section{Immunofluorescence}

Fresh brains of rats were isolated and embedded by OTC (Sakura Finetek Japan Co., Ltd, Tokyo, Japan), and then, they were cut to get frozen $10 \mu \mathrm{m}$ sections. After slices were repaired in the high-pressure cooker by citrate antigen retrieval solution (Beyotime, Shanghhai, China, Catalogue No.: P0081) and blocked by $5 \%$ normal goat serum (Beyotime, Shanghai, China, Catalogue No.: C0265) (1 hour at room temperature). They were incubated with rabbitanti-rat primary antibody to GLP-1R (Santa Cruz Biotechnology, Inc., Dallas, TX, USA, Catalogue No.: 
sc-390774) and PPAR- $\gamma$ (Santa Cruz Biotechnology, Inc., Dallas, TX, USA, Catalogue No.: sc-390740) at $4^{\circ} \mathrm{C}$ overnight. After washing for 3 times, Alexa Fluor 594 conjugated goat-anti-rabbit secondary antibody (Proteintech, Wuhan, China, Catalogue No.: SA00013-3) was used to detect the primary antibody. Finally, sections were stained by DAPI (Beyotime, Shanghhai, China, Catalogue No.: P0131) and washed for 3 times with PBS. GLP-1R (PPAR- $\gamma$ ) and DAPI (in hippocampal dentate gyrus and cortex) were observed by a fluorescence microscope (Olympus, Japan) after triggered at $594 \mathrm{~nm}$ and $358 \mathrm{~nm}$ respectively. Image were captured by (CellSens Standard).

\section{Statistical analysis}

All data were described as mean \pm standard deviation. Statistical differences were determined by using Student's t-tests, and one-way ANOVA followed by LSD for multiple-comparison tests. Data were analysis by SPSS 22.0 (SPSS Inc., Chicago, IL, USA). P $<0.05$ was considered as significant difference.

\section{RESULTS}

\section{CML induced PC12 cells apoptosis}

To investigate the effect of CML on cells viability, CML $(0,12.5,25,50,75$ and $100 \mu \mathrm{g} / \mathrm{ml})$ was used to treat PC12 cells for 6,12 , and 24 hours (supplementary Figure $1 \mathrm{~A}-1 \mathrm{C})$. We found significant cells viability decline at 24 hours in the medium with 50, 75, and 100 $\mu \mathrm{g} / \mathrm{ml}$ CML (Supplementary Figure 1C). And then, we detected the levels of apoptosis by TUNEL assay. Indeed, increased apoptosis in PC12 cells was observed with $50 \mu \mathrm{g} / \mathrm{ml} \mathrm{CML}$, compared with that without CML (Figure 1A). Additionally, Compared with PC12 cells in medium without CML, we measured down-regulated bcl2 level and up-regulated bax level in PC12 cells with CML $(50 \mu \mathrm{g} / \mathrm{ml})$ (Figure 1B, 1C).

\section{CML down-regulated GLP-1R and PPAR- $\gamma$ levels in PC12 cells}

GLP-1R and PPAR- $\gamma$ levels were also measured in PC12 cells stimulated by CML. GLP-1R and PPAR- $\gamma$
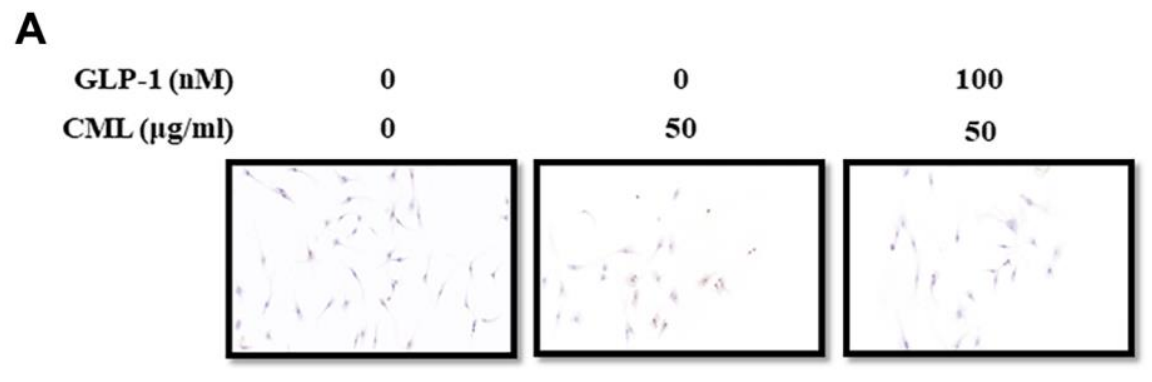

B

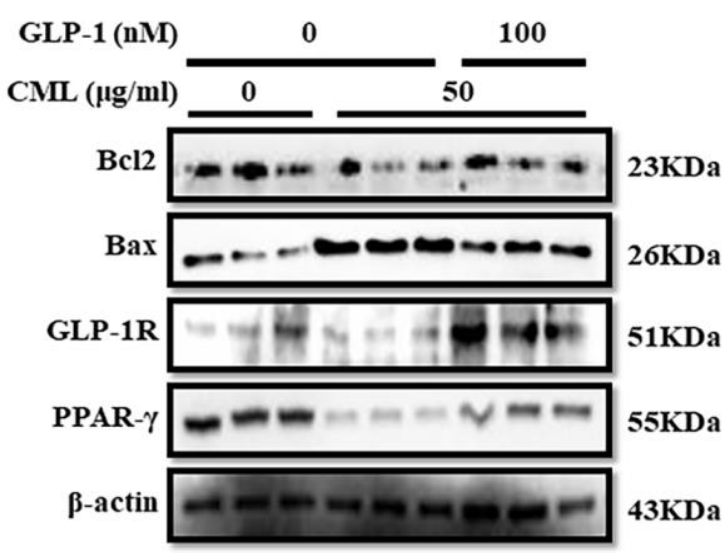

C

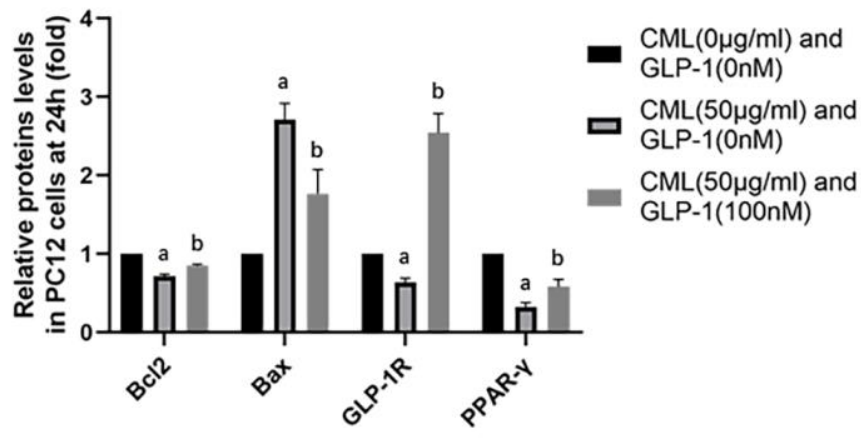

Figure 1. GLP-1 attenuated apoptosis of PC12 cells induced by CML. Results in (A) showed that GLP-1 restored the PC12 cells apoptosis induced by CML. (B) Showed the western blotting results of bcl2, bax, GLP-1R and PPAR- $\gamma$. "a" in (C) showed the down-regulated bcl2, PPAR- $\gamma$ and GLP-1R as well as up-regulated bax in PC12 cells with $50 \mu \mathrm{g} / \mathrm{ml} \mathrm{CML,} \mathrm{compared} \mathrm{with} \mathrm{those} \mathrm{without} \mathrm{CML} \mathrm{(all} P<0.05$ ). "b" in (C) showed up-regulated bcl2, PPAR- $\gamma$ and GLP-1R as well as down-regulated bax in PC12 cells with $50 \mu \mathrm{g} / \mathrm{ml} \mathrm{CML}$ and $100 \mathrm{nM} / \mathrm{ml} \mathrm{GLP}-1$, compared with those with $50 \mu \mathrm{g} / \mathrm{ml} \mathrm{CML} \mathrm{but} \mathrm{without} \mathrm{GLP-1} \mathrm{(all} P<0.05$ ). Data are represented as mean \pm SD; $\mathrm{n}=3$ per group for results of western blotting. 
levels were significantly down-regulated by CML with a concentration of $50 \mu \mathrm{g} / \mathrm{ml}$ (Figure 1B, 1C).

GLP-1 treatment restored the apoptosis and upregulated PPAR- $\gamma$ levels

CML $(50 \mu \mathrm{g} / \mathrm{ml})$ medicated PC12 cells viability declines were restored by GLP-1 at concentrations of $100 \mathrm{nM}$, $200 \mathrm{nM}$, and $500 \mathrm{nM}$ in PC12 cells (Supplementary Figure 1D). In addition, decreased apoptosis was observed in PC12 cells treated with GLP-1 by TUNEL assay (Figure 1A). Furthermore, we showed upregulation of bcl2 and down-regulation of bax in PC12 cells treat with GLP-1 at a concentration of $100 \mathrm{nM}$ for 24 hours (Figure 1B, 1C). To further explore the mechanism of the protecting effect of GLP-1 from apoptosis in neurons, levels of PPAR- $\gamma$ and GLP-1R were measured. Higher PPAR- $\gamma$ and GLP-1R levels were measured in CML treated PC12 cells with GLP-1 than that without GLP-1 (Figure 1B, 1C).

A

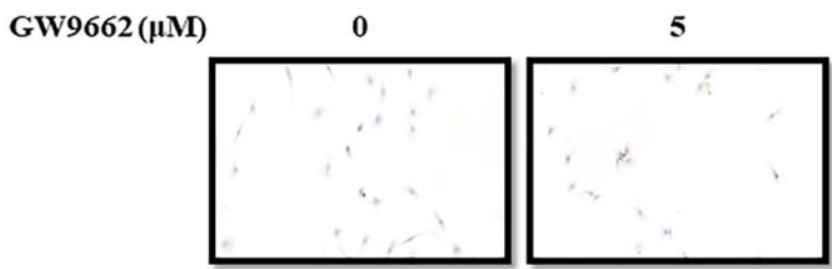

C

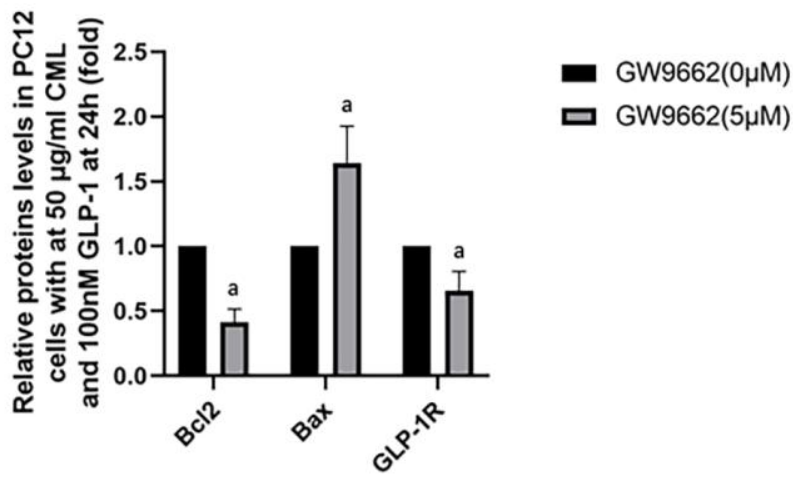

Inhibition of PPAR- $\gamma$ abolished the protective effect of GLP-1 and impaired the expression of GLP-1R

To clarify the important role of PPAR- $\gamma$ involved in the process of GLP-1 alleviated PC12 apoptosis, GW9662, a selective inhibitor of PPAR- $\gamma$, was used to block the function of PPAR- $\gamma$. Interestingly, GW9662 (5, 10, 20, and $50 \mu \mathrm{M}$ ) significantly decreased the viability of PC12 cells with $50 \mu \mathrm{g} / \mathrm{ml}$ and 100nM GLP-1 at 24 hours (Supplementary Figure 1E). In addition, $5 \mu \mathrm{M}$ GW9662 abolished the protective effect of GLP-1 from CML induced apoptosis detected by TUNEL assay (Figure 2A) or showed by bax or bcl2 levels (Figure 2B, $2 C)$. Furthermore, the blocking of PPAR- $\gamma$ also decreased the levels of GLP-1R in PC12 cells (Figure $2 \mathrm{~B}, 2 \mathrm{C})$. To investigate the association between GLP$1 \mathrm{R}$ and PPAR- $\gamma$, ChIP assay was conducted. Surprisingly, we detected the promoter sequence of GLP-1R in the mixture pulled down by PPAR- $\gamma$ antibody (Figure 2D).

B

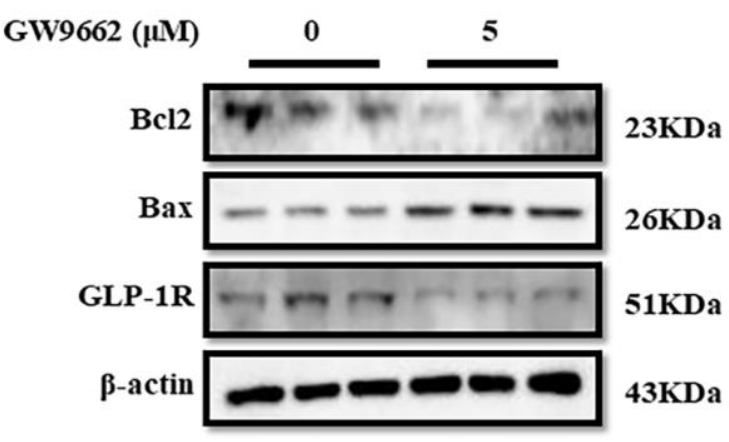

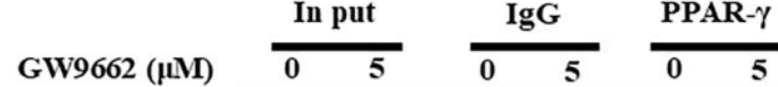
GLP-1R promote

Figure 2. PPAR- $\gamma$ inhibition abolished the protective effect of GLP-1 on PC12 cells from apoptosis induced by CML. Results in (A) showed GW9662 abolished the protective effect of GLP-1 on PC12 cells from apoptosis induced by CML. (B) Showed the western blotting results of bcl2, bax, and GLP-1R. "a" in (C) showed the down-regulated bcl2 and GLP-1R as well as up-regulated bax levels between PC12 cells (treated by 50ug/ml CML and $100 \mathrm{nM} \mathrm{GLP-1)} \mathrm{with} \mathrm{and} \mathrm{without} \mathrm{5uM} \mathrm{GW9662.} \mathrm{Results} \mathrm{in} \mathrm{(D)} \mathrm{showed} \mathrm{the} \mathrm{direct}$ interactivity between PPAR- $\gamma$ and GLP-1R promoter sequence. Data are represented as mean \pm SD; $n=3$ per group for results of western blotting. 


\section{Diabetic rats showed cognitive dysfunction}

To confirm the cognitive function impairment in diabetes, Wistar rats (aged 6 weeks) were injected with a large doze of STZ. After 8 weeks, Morris water maze tests were performed to compare the cognitive function of rats with and without diabetes (Figure 3A). The path of rats found the target platform was showed in (Supplementary Figure 2A). Indeed, compare to control rats without diabetes, diabetic rats showed longer escape latency and path length after 5 days training (Supplementary Figure 2B, 2C). Furthermore, decreased percentage of time spend in the target quadrant and frequency of crossing platform area were recorded in rat with diabetes (Supplementary Figure 2D, 2E).
Presence of increased CML and decreased GLP-1 in diabetic rats

After the tests of cognitive function, plasmatic CML and GLP-1 levels were measured to explore the reasons of diabetic cognition decline. CML levels elevated more than 4 times, while GLP-1 levels decreased nearly half (Figure 3B, 3C) in diabetic rats. To further explore the reason of diabetic cognition decline, the sizes of brains were observed (Supplementary Figure 2F). However, we did not find any difference in brain sizes between control rats and diabetic rats. While increased CML, decreased GLP-1 levels in hippocampus and cortex were measured by ELISA (Figure 4A, 4B as well as Figure 5A, 5B).
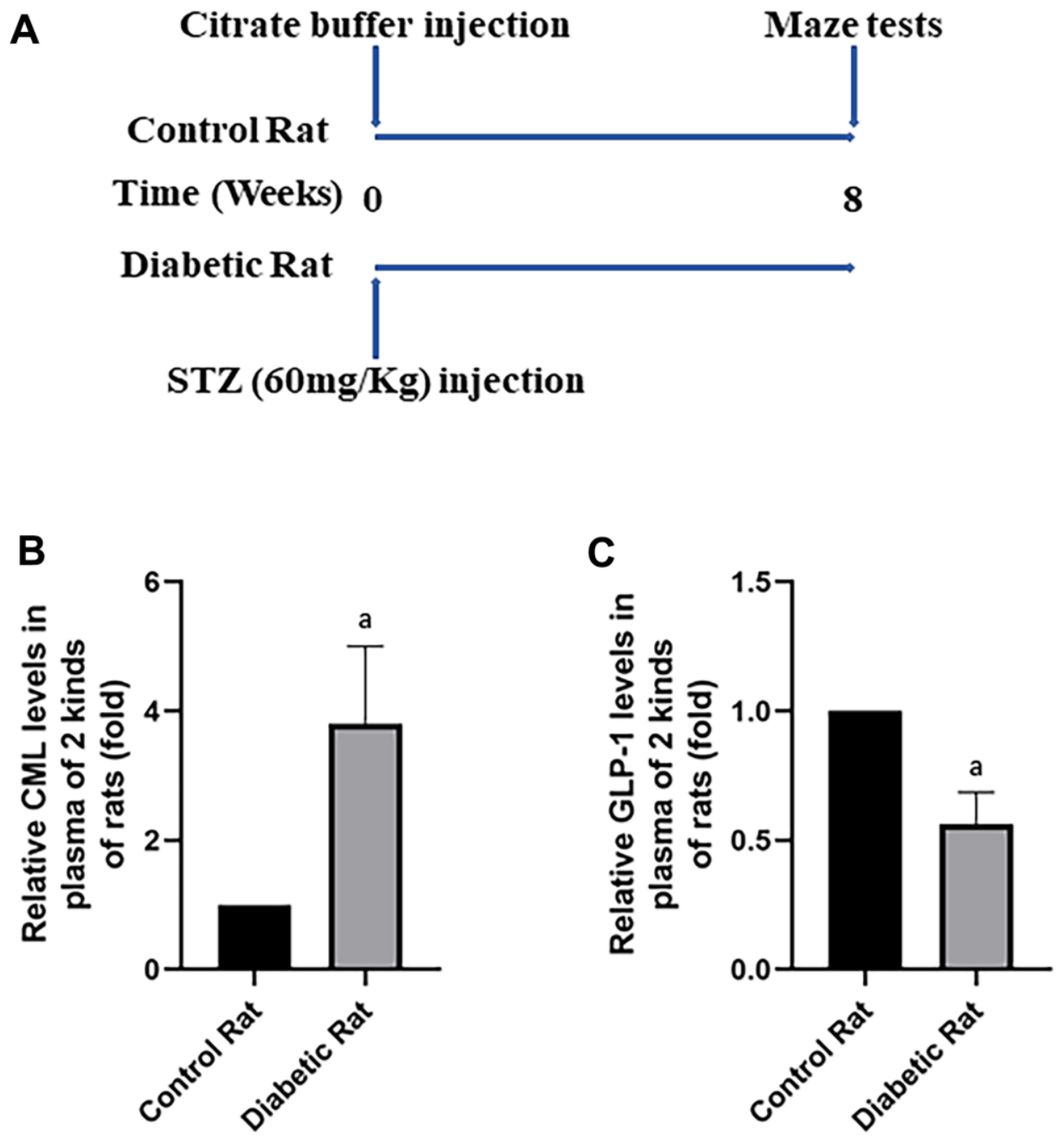

Figure 3. Diabetic rats showed increased CML and decreased GLP-1 levels in plasma. In (A), we showed treatments of Wistar rats. Each rat was given a large doze of STZ or citrate buffer (PH 4.5) to get diabetic rat or control rat. After 8 weeks, cognitive functions of all rats were tested by water maze. "a" in (B) showed increased CML levels, while in (C) showed decreased GLP-1 levels in the plasma of diabetic rats, compared with control rats. Data are represented as mean $\pm S D ; n=4$ per group for results of ELISA. 
Diabetic rats showed more cells apoptosis as well as decreased GLP-1R and PPAR- $\gamma$ in brain

Here, we observed the apoptosis in hippocampus and cortex by TUNEL assay. Interestingly, we not only detected more apoptosis in hippocampus but also in cortex tissue in diabetic rats than control rats (Figures 4C, 5C). Additionally, bcl2 and bax levels were measured to confirm the apoptosis. Indeed, elevated bax levels were discovered in diabetic rats, compared to rats without diabetes. Moreover, bcl2 levels are higher in control rats than rats with diabetes (Figure $4 \mathrm{E}, 4 \mathrm{~F}$ as well as Figure 5E, 5F). The above results showed impaired GLP-1 levels in plasma and brain as well as neuronal apoptosis of diabetic rats. Therefore, GLP-1R levels in hippocampus and cortex were also measured. Down-regulated GLP-1R levels were found in these two parts of diabetic cerebrum by immunofluorescence and western blotting. Furthermore, PPAR$\gamma$ levels were also down-regulated detected by immunofluorescence and western blotting (Figure 4D4F as well as Figure 5D-5F).

\section{DISCUSSION}

$\mathrm{AD}$ is a huge challenge [5] worldwide, with limited efficient therapy. This pathology processes with three phases, (a) a preclinical period, beginning with asymptomatic accumulation of $A \beta$, leading to early neurodegeneration and then to subtle cognitive symptoms [42, 43], (b) a prodromal period, MCI [44, 45]; and (c) dementia due to $\mathrm{AD}$ [46]. T2DM is associated with MCI [47], and a risk factor for MCI progressing to dementia due to AD [48]. Neuronal apoptosis runs through these three stages. Hyperglycemia is the most important risk factor of cognitive decline in T2DM patients and promotes the conversion of MCI patients to those with AD. AGEs are formed in the condition of hyperglycemia in diabetes and associated with diabetic complications [49]. CML is a certain component of AGEs [33]. So, CML was used to induce the apoptosis of PC12 cells. Indeed, PC12 cells apoptosis levels were elevated by CML. GLP-1 and its analogue, showed their neuroprotective effect in mice $[23,24]$ and human [50] via binding to GLP-1R.
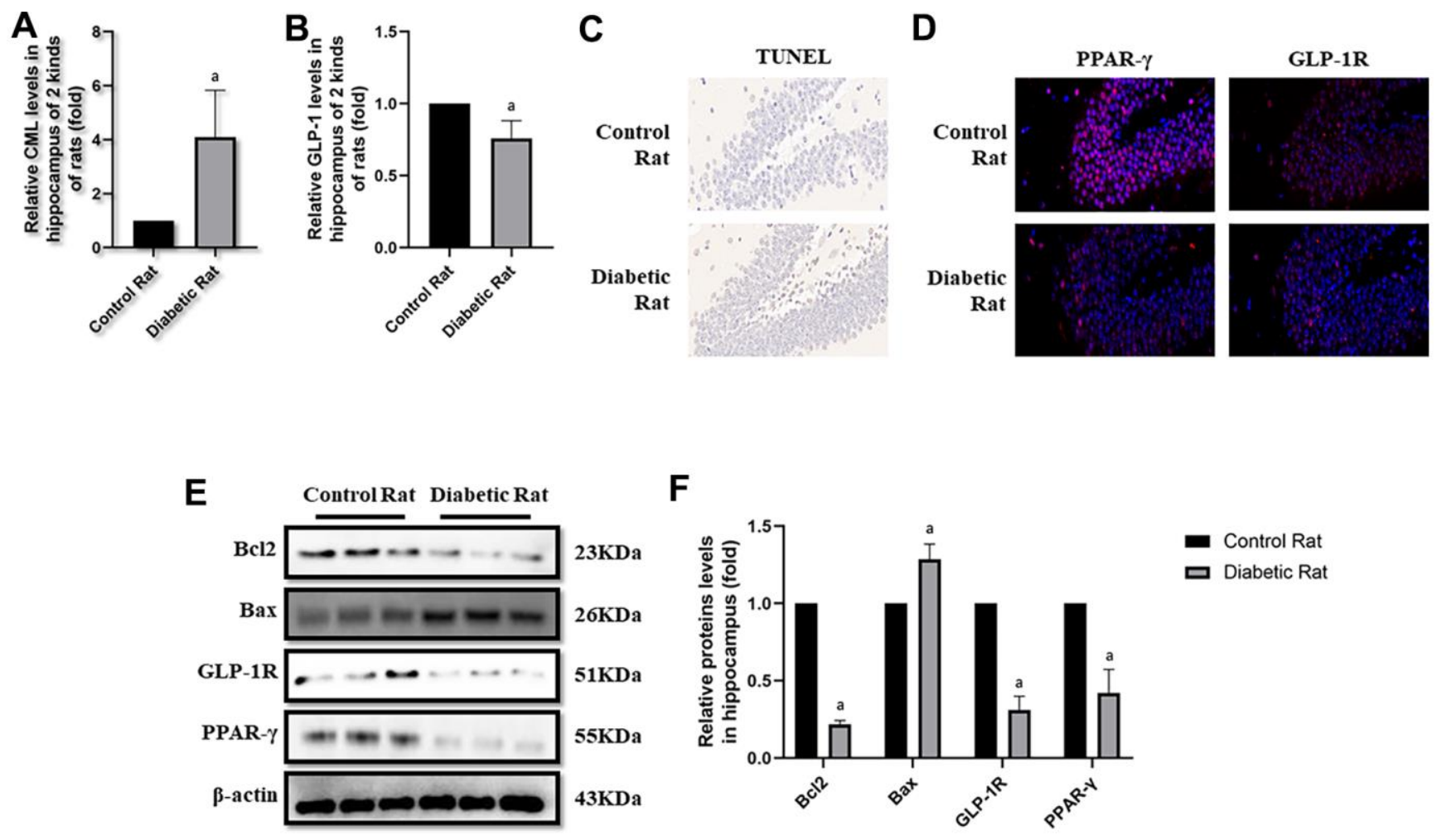

Figure 4. Levels of apoptosis were elevated in hippocampus of diabetic rats. "a" in (A) showed elevated CML levels in hippocampus of diabetic rats, compared with control rats $(P<0.05)$. "a" in $(B)$ showed decreased GLP-1 levels in hippocampus of diabetic rats, compared with control rats $(P<0.05)$. Results in $(C)$ showed increased apoptosis in hippocampus of diabetic rats, compared with control rats. Results in (D) showed down-regulated PPAR- $\gamma$ and GLP-1R in hippocampus of diabetic rats, compared with control rats. (E) Showed the western blotting results of bcl2, bax, GLP-1R and PPAR- $\psi$. "a" of (F) showed down-regulated bcl2, GLP-1R and PPAR- $\gamma$ levels and up-regulated bax levels in hippocampus of diabetic rats, compared with control rats (all $P<0.05$ ). Data are represented as mean $\pm S D ; n=4$ per group for results of ELISA. $\mathrm{n}=3$ per group for results of western blotting. 
So, we guess that GLP-1 could regulate CML induced damage, including apoptosis in PC12 cells by binding to GLP-1R. To verify our hypothesis, GLP-1 treatment administrations were performed. We demonstrated more apoptotic cells in the medium with CML than that the medium without CML. Results in this present study are consistent with the research of Chen et al, showed AGEs activated apoptosis in SHSY5Y cells [12]. Interestingly, we found a decreased GLP-1R levels in PC12 cells stimulated by CML. Similarly, GLP-1R defective mice showed declined cognition [25], and restored by GLP-1R overexpression [51]. PPAR- $\gamma$, an important receptor associated with apoptosis and proliferation in several kinds of cells [29, 52-54], including neurons [55, 56], is also regulated by AGEs in diabetes $[30,57]$. In this work, PPAR- $\gamma$ levels were down-regulated by CML. Additionally, cellular apoptosis triggered by CML was alleviated by GLP-1. This indicated the neuroprotective effect of GLP-1. Indeed, liraglutide and lixisenatide, analogues of GLP-1, could cross the $\mathrm{BBB}$ to play a role of neuroprotection [58, 59].
Although most GLP-1 was secreted by intestinal L cells [14], and inactivated by DPP-4 within 2 minutes [60], several cells in the brain could also produce an amount of GLP-1 [19, 20]. Moreover, GLP-1 significantly increased levels of PPAR $-\gamma$ and GLP-1R down-regulated by CML.

Although GLP-1R and PPAR- $\gamma$ play their important role in apoptosis, the interaction between them in CML induced apoptosis remains uncertain. To further determine the role of PPAR- $\gamma$ in GLP- 1 alleviated neuronal apoptosis, PPAR- $\gamma$ blocking assay was performed in PC12 cells damaged by CML and remedied by GLP-1. Not surprisingly, GW9662, a specific blocker of PPAR- $\gamma$, abolished the protective effect of GLP-1 on PC12 cells from CML induced apoptosis. Additionally, the promoter sequence of GLP-1R was detected in the mixture pulled down by PPAR- $\gamma$ antibody. These above results showed that GLP-1R expression may be regulated PPAR- $\gamma$ located in nuclear via binding to the promoter of GLP-1R.
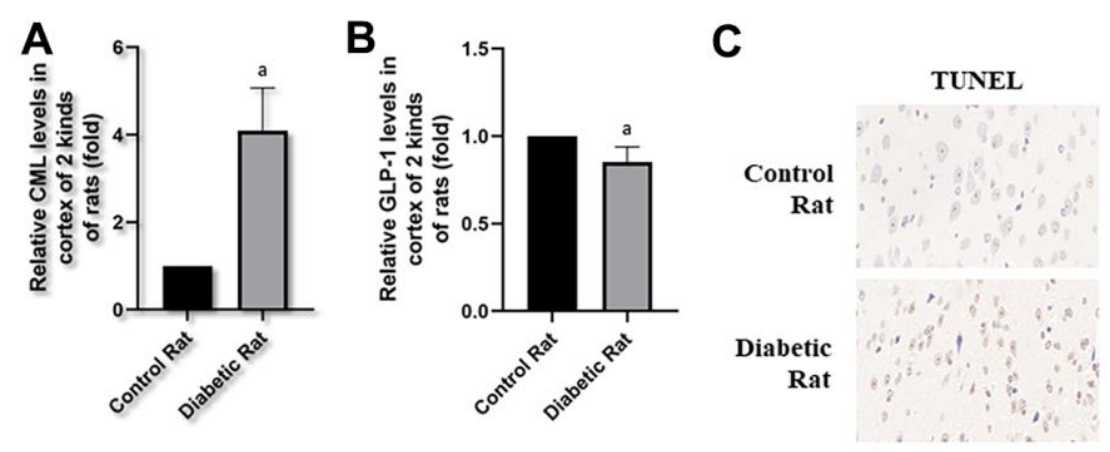

D
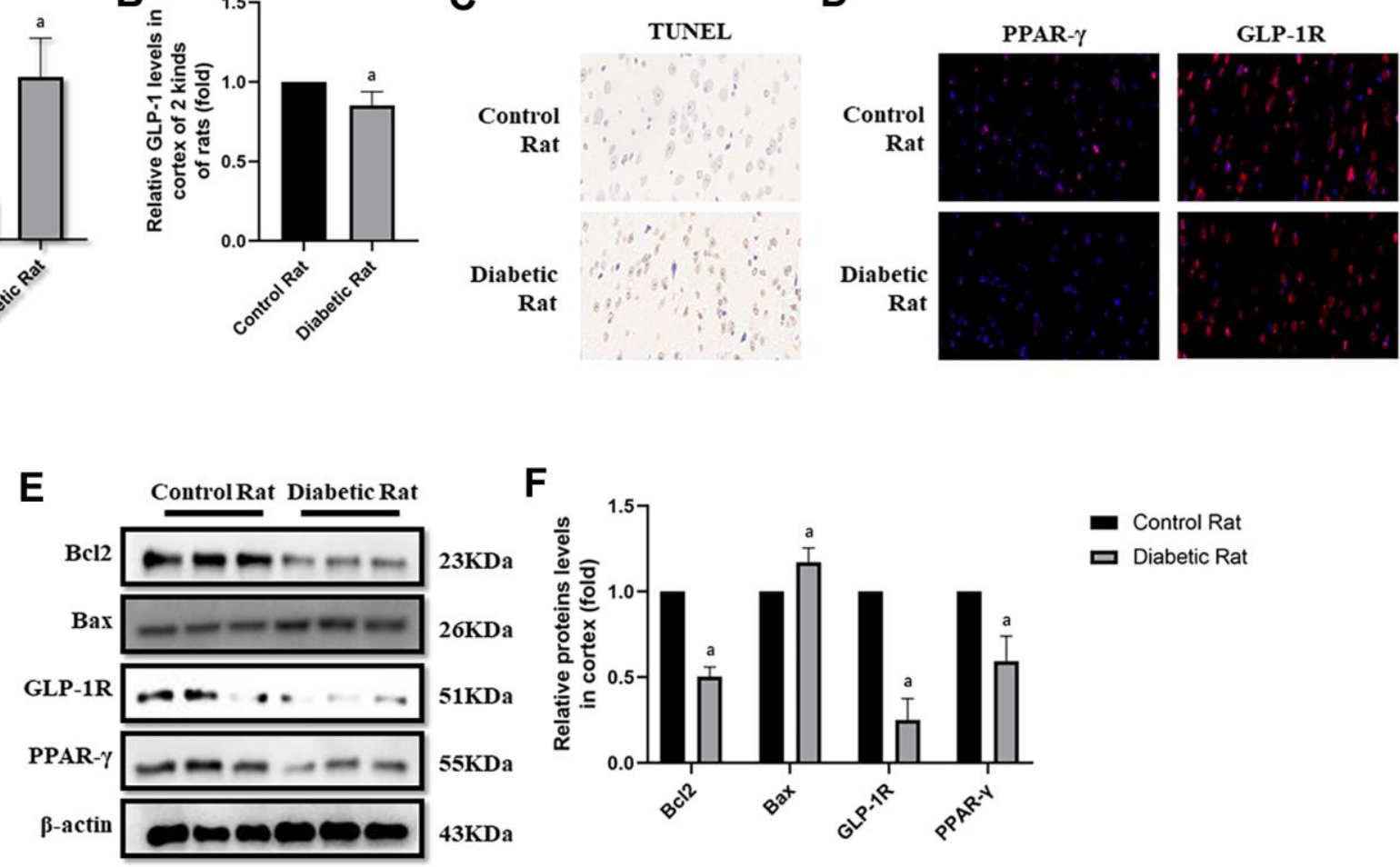

Figure 5. Levels of cells apoptosis were elevated in cortex of diabetic rats. "a" in (A) showed elevated CML levels in cortex of diabetic rats, compared with control rats $(P<0.05)$. "a" in (B) showed decreased GLP-1 levels in cortex of diabetic rats, compared with control rats $(P<0.05)$. Results in $(C)$ showed increased apoptosis in cortex of diabetic rats, compared with control rats. Results in (D) showed downregulated PPAR- $\gamma$ and GLP-1R in cortex of diabetic rats, compared with control rats. (E) Showed the western blotting results of bcl2, bax, GLP$1 R$ and PPAR- $\gamma$. "a" of (F) showed down-regulated bcl2, GLP-1R and PPAR- $\gamma$ levels and up-regulated bax levels in cortex of diabetic rats, compared with control rats (all $P<0.05$ ). Data are represented as mean $\pm S D ; n=4$ per group for results of ELISA. $n=3$ per group for results of western blotting. 
In order to confirm the protective effect of GLP-1 on neuronal apoptosis found in vitro, diabetic rats induced by STZ were used in vivo. Additionally, water maze was used to test their cognitive function. Indeed, we found significant cognitive dysfunction in diabetic rat. To confirm the effects of CML and GLP1 in animal study, their levels were measured in plasma and brain of diabetic rats. Interestingly, we not only detected increased CML and decreased GLP-1 levels, but also observed elevated cells apoptosis levels in diabetic rats. These results determined that GLP-1 may involve in CML triggered cells apoptosis in the model of diabetic rats. To clarify the role of GLP-1 in apoptosis, GLP-1R was measured in hippocampus and cortex. We have already detected the interaction between PPAR- $\gamma$ and GLP-1R promoter in vitro. In addition, PPAR- $\gamma$ plays a promising role in neuroprotective effect may contribute to prevent apoptosis from AGEs [29, 30]. To further confirm the role of PPAR- $\gamma$ in the neuroprotective effect of GLP-1, GLP-1R and PPAR$\gamma$ levels were also observed in the brain of rats with or without diabetes. Indeed, decreased GLP-1R and PPAR- $\gamma$ levels were measured in the tissue of hippocampus and cortex. So, we suppose that GLP-1 may involve in neuronal apoptosis via PPAR- $\gamma$ in diabetic rats with increased plasmatic CML levels.

In general, we demonstrated that GLP-1 may protect neurons from apoptosis in diabetes. Additionally, PPAR- $\gamma$ is involved in this process (Figure 6). However, the mechanism involves in regulation of PPAR- $\gamma$ by GLP-1 needs further exploration in the future research, especially for the animal experiments with GLP-1 analogues and PPAR- $\gamma$ inhibitor. Despite these limitations, we still advocate bioactive GLP-1R agonists (Cannot be degraded by DPP4 inhibitors), was used for animal experiment, even for clinical patients with diabetic cognitive impairment or with higher risk of diabetic cognition decline.

\section{CONCLUSIONS}

In conclusion, we indicated that GLP-1 may attenuate CML induced neuronal apoptosis via PPAR- $\gamma$, at least depends on PPAR- $\gamma$ regulated GLP-1R expression partly. However, the mechanism of PPAR $-\gamma$ regulated by GLP-1 remains need further study in our future work.

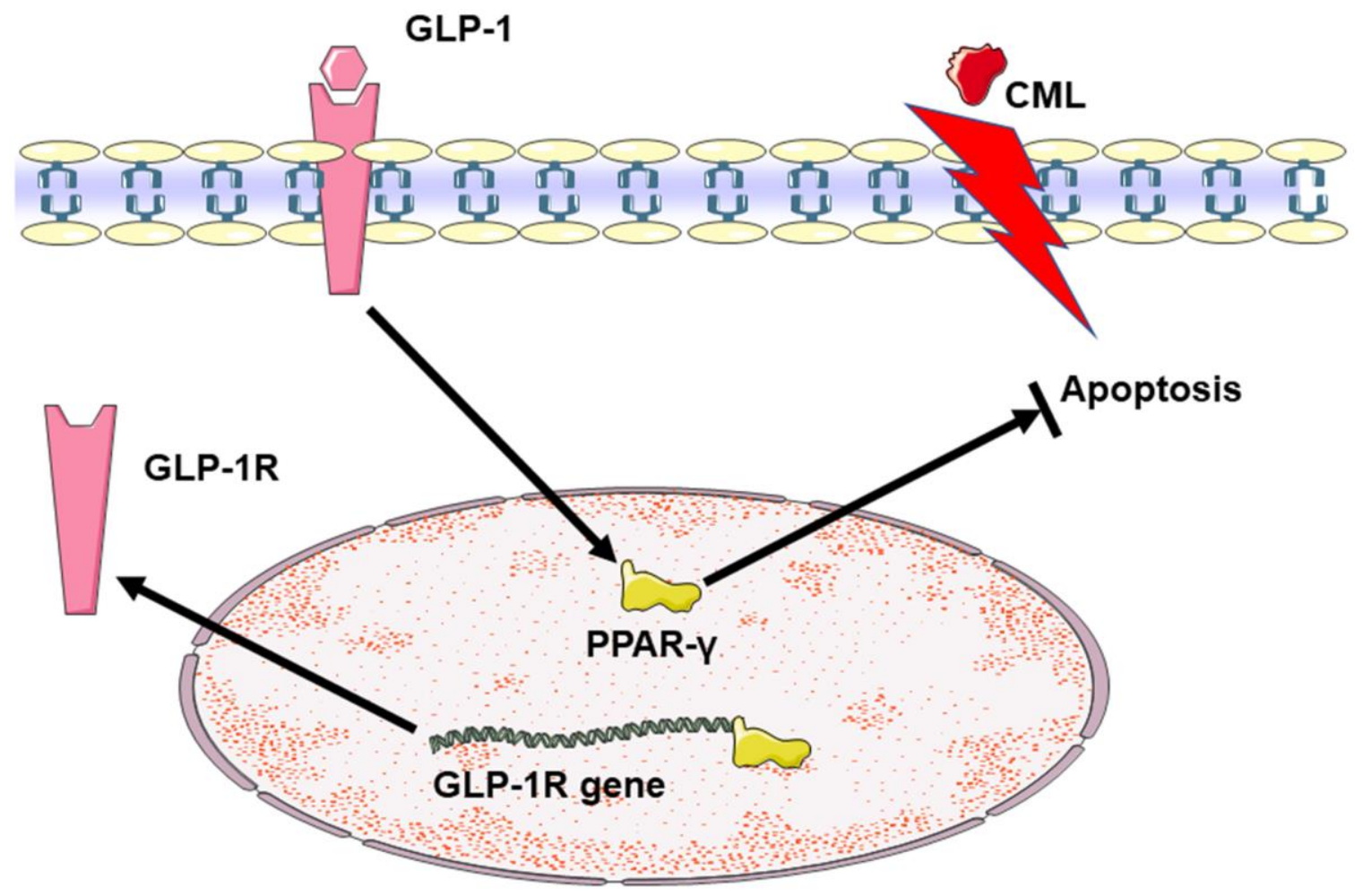

Figure 6. Summary diagram of the relationship among GLP-1, CML and PPAR in cells apoptosis. CML could induce the apoptosis of PC12 cells. GLP-1 could induce the expression of PPAR- $\gamma$ by binding to GLP-1R. And then, PPAR- $\gamma$ could attenuate the neuronal apoptosis. Additionally, PPAR- $\gamma$ may promote the expression of GLP-1R by the interaction between PPAR- $\gamma$ and the promoter sequence of GLP-1R. 


\section{AUTHOR CONTRIBUTIONS}

Shaohua Wang conceived the idea; directed the work and designed the experiments; Haoqiang Zhang, Bing Song, Wenwen Zhu, Lili Liu, Xiqiao He, Zheng Wang, $\mathrm{Ke}$ An, Wuyou Cao, and Jijing Shi performed the experiments, analyzed the data. Haoqiang Zhang and Shaohua Wang wrote and revised the manuscript. All authors discussed the reviewed and approved the final manuscript.

\section{CONFLICTS OF INTEREST}

The authors declare that they have no conflicts of interest.

\section{FUNDING}

This work was partially supported by the National Natural Science Foundation of China (No.81570732, SW and No. 81370921, SW).

\section{REFERENCES}

1. Chan JC, Zhang Y, Ning G. Diabetes in China: a societal solution for a personal challenge. Lancet Diabetes Endocrinol. 2014; 2:969-79. https://doi.org/10.1016/S2213-8587(14)70144-5 PMID:25218728

2. Wang $L$, Gao $P$, Zhang $M$, Huang $Z$, Zhang $D$, Deng $Q$, Li Y, Zhao Z, Qin X, Jin D, Zhou M, Tang X, Hu Y, Wang L. Prevalence and Ethnic Pattern of Diabetes and Prediabetes in China in 2013. JAMA. 2017; 317: 2515-23.

https://doi.org/10.1001/jama.2017.7596

PMID:28655017

3. Xu $Y$, Wang $L$, He J, Bi $Y$, Li $M$, Wang $T$, Wang $L$, Jiang $Y$, Dai M, Lu J, Xu M, Li Y, Hu N, et al, and 2010 China Noncommunicable Disease Surveillance Group. Prevalence and control of diabetes in Chinese adults. JAMA. 2013; 310:948-59.

https://doi.org/10.1001/jama.2013.168118 PMID:24002281

4. Cho NH, Shaw JE, Karuranga S, Huang $\mathrm{Y}$, da Rocha Fernandes JD, Ohlrogge AW, Malanda B. IDF Diabetes Atlas: Global estimates of diabetes prevalence for 2017 and projections for 2045. Diabetes Res Clin Pract. 2018; 138:271-81.

https://doi.org/10.1016/j.diabres.2018.02.023 PMID:29496507

5. Alzheimer's Association. 2016 Alzheimer's disease facts and figures. Alzheimers Dement. 2016; 12:459-509. https://doi.org/10.1016/j.jalz.2016.03.001 PMID:27570871
6. Alexiou A, Kamal MA, Ashraf GM. Editorial: The Alzheimer's Disease Challenge. Front Neurosci. 2019; 13:768.

https://doi.org/10.3389/fnins.2019.00768 PMID:31396043

7. Yang Y, Song W. Molecular links between Alzheimer's disease and diabetes mellitus. Neuroscience. 2013; 250:140-50. https://doi.org/10.1016/i.neuroscience.2013.07.009 PMID:23867771

8. Boccardi V, Murasecco I, Mecocci P. Diabetes drugs in the fight against Alzheimer's disease. Ageing Res Rev. 2019; 54:100936.

https://doi.org/10.1016/j.arr.2019.100936 PMID:31330313

9. McCrimmon RJ, Ryan CM, Frier BM. Diabetes and cognitive dysfunction. Lancet. 2012; 379:2291-99.

https://doi.org/10.1016/S0140-6736(12)60360-2 PMID:22683129

10. Huang R, Tian S, Zhang H, Zhu W, Wang S. Chronic hyperglycemia induces tau hyperphosphorylation by downregulating OGT-involved O-GIcNAcylation in vivo and in vitro. Brain Res Bull. 2020; 156:76-85.

https://doi.org/10.1016/i.brainresbull.2020.01.006 PMID:31931119

11. Swomley AM, Butterfield DA. Oxidative stress in Alzheimer disease and mild cognitive impairment: evidence from human data provided by redox proteomics. Arch Toxicol. 2015; 89:1669-80.

https://doi.org/10.1007/s00204-015-1556-z PMID:26126631

12. Chen S, Yin L, Xu Z, An FM, Liu AR, Wang Y, Yao WB, Gao XD. Inhibiting receptor for advanced glycation end product (AGE) and oxidative stress involved in the protective effect mediated by glucagon-like peptide-1 receptor on AGE induced neuronal apoptosis. Neurosci Lett. 2016; 612:193-98.

https://doi.org/10.1016/i.neulet.2015.12.007 PMID:26679229

13. Chen S, Liu AR, An FM, Yao WB, Gao XD. Amelioration of neurodegenerative changes in cellular and rat models of diabetes-related Alzheimer's disease by exendin-4. Age (Dordr). 2012; 34:1211-24.

https://doi.org/10.1007/s11357-011-9303-8 PMID:21901364

14. Kieffer TJ, Habener JF. The glucagon-like peptides. Endocr Rev. 1999; 20:876-913.

https://doi.org/10.1210/edrv.20.6.0385

PMID:10605628

15. Hare KJ, Vilsbøll T, Asmar M, Deacon CF, Knop FK, Holst JJ. The glucagonostatic and insulinotropic effects of 
glucagon-like peptide 1 contribute equally to its glucose-lowering action. Diabetes. 2010; 59:1765-70. https://doi.org/10.2337/db09-1414 PMID:20150286

16. Brubaker PL, Drucker DJ. Structure-function of the glucagon receptor family of $G$ protein-coupled receptors: the glucagon, GIP, GLP-1, and GLP-2 receptors. Recept Channels. 2002; 8:179-88.

https://doi.org/10.3109/10606820213687

PMID:12529935

17. Körner M, Stöckli M, Waser B, Reubi JC. GLP-1 receptor expression in human tumors and human normal tissues: potential for in vivo targeting. J Nucl Med. 2007; 48:736-43.

https://doi.org/10.2967/jnumed.106.038679

PMID:17475961

18. Wei Y, Mojsov S. Tissue-specific expression of the human receptor for glucagon-like peptide-l: brain, heart and pancreatic forms have the same deduced amino acid sequences. FEBS Lett. 1995; 358:219-24. https://doi.org/10.1016/0014-5793(94)01430-9 PMID:

19. Kappe C, Tracy LM, Patrone C, Iverfeldt K, Sjöholm Å. GLP-1 secretion by microglial cells and decreased CNS expression in obesity. J Neuroinflammation. 2012; 9:276.

https://doi.org/10.1186/1742-2094-9-276

PMID:23259618

20. Vrang N, Hansen M, Larsen PJ, Tang-Christensen M. Characterization of brainstem preproglucagon projections to the paraventricular and dorsomedial hypothalamic nuclei. Brain Res. 2007; 1149:118-26. https://doi.org/10.1016/i.brainres.2007.02.043 PMID:17433266

21. Li C, Liu W, Li X, Zhang Z, Qi H, Liu S, Yan N, Xing Y, Hölscher C, Wang Z. The novel GLP-1/GIP analogue DA5-CH reduces tau phosphorylation and normalizes theta rhythm in the icv. STZ rat model of AD. Brain Behav. 2020; 10:e01505.

https://doi.org/10.1002/brb3.1505 PMID:31960630

22. Wang ZJ, Han YF, Zhao F, Yang GZ, Yuan L, Cai HY, Yang JT, Holscher C, Qi JS, Wu MN. A dual GLP-1 and Gcg receptor agonist rescues spatial memory and synaptic plasticity in APP/PS1 transgenic mice. Horm Behav. 2020; 118:104640.

https://doi.org/10.1016/i.yhbeh.2019.104640

PMID:31765661

23. Iwai T, Suzuki M, Kobayashi K, Mori K, Mogi Y, Oka J. The influences of juvenile diabetes on memory and hippocampal plasticity in rats: improving effects of glucagon-like peptide-1. Neurosci Res. 2009; 64:67-74. https://doi.org/10.1016/i.neures.2009.01.013 PMID:19321133
24. McClean PL, Parthsarathy V, Faivre E, Hölscher C. The diabetes drug liraglutide prevents degenerative processes in a mouse model of Alzheimer's disease. J Neurosci. 2011; 31:6587-94.

https://doi.org/10.1523/JNEUROSCI.0529-11.2011 PMID:21525299

25. During MJ, Cao L, Zuzga DS, Francis JS, Fitzsimons HL, Jiao X, Bland RJ, Klugmann M, Banks WA, Drucker DJ, Haile CN. Glucagon-like peptide-1 receptor is involved in learning and neuroprotection. Nat Med. 2003; 9:1173-79.

https://doi.org/10.1038/nm919 PMID: 12925848

26. Li Y, Li Q, Wang C, Lou Z, Li Q. Trigonelline reduced diabetic nephropathy and insulin resistance in type 2 diabetic rats through peroxisome proliferator-activated receptor- $\gamma$. Exp Ther Med. 2019; 18:1331-37.

https://doi.org/10.3892/etm.2019.7698

PMID:31363374

27. Machado MM, Bassani TB, Cóppola-Segovia V, Moura EL, Zanata SM, Andreatini R, Vital MA. PPAR- $\gamma$ agonist pioglitazone reduces microglial proliferation and NF-kB activation in the substantia nigra in the 6hydroxydopamine model of Parkinson's disease. Pharmacol Rep. 2019; 71:556-64.

https://doi.org/10.1016/j.pharep.2018.11.005 PMID:31132685

28. Dinda B, Dinda M, Kulsi G, Chakraborty A, Dinda S. Therapeutic potentials of plant iridoids in Alzheimer's and Parkinson's diseases: A review. Eur J Med Chem. 2019; 169:185-99.

https://doi.org/10.1016/i.ejmech.2019.03.009 PMID:30877973

29. Giampietro L, Gallorini M, De Filippis B, Amoroso R, Cataldi A, di Giacomo V. PPAR- $\gamma$ agonist GL516 reduces oxidative stress and apoptosis occurrence in a rat astrocyte cell line. Neurochem Int. 2019; 126:239-45. https://doi.org/10.1016/i.neuint.2019.03.021 PMID: $\underline{0946848}$

30. Tabassum A, Mahboob T. Role of peroxisome proliferator-activated receptor-gamma activation on visfatin, advanced glycation end products, and renal oxidative stress in obesity-induced type 2 diabetes mellitus. Hum Exp Toxicol. 2018; 37:1187-98. https://doi.org/10.1177/0960327118757588 PMID:29441829

31. Onuma H, Inukai K, Kitahara A, Moriya R, Nishida S, Tanaka T, Katsuta H, Takahashi K, Sumitani Y, Hosaka T, Ishida $\mathrm{H}$. The glucagon-like peptide 1 receptor agonist enhances intrinsic peroxisome proliferator-activated receptor $\gamma$ activity in endothelial cells. Biochem Biophys Res Commun. 2014; 451:339-44.

https://doi.org/10.1016/i.bbrc.2014.07.136 PMID:25109805 
32. Svegliati-Baroni G, Saccomanno S, Rychlicki C, Agostinelli L, De Minicis S, Candelaresi C, Faraci G, Pacetti D, Vivarelli M, Nicolini D, Garelli P, Casini A, Manco $M$, et al. Glucagon-like peptide-1 receptor activation stimulates hepatic lipid oxidation and restores hepatic signalling alteration induced by a highfat diet in nonalcoholic steatohepatitis. Liver Int. 2011; 31:1285-97.

https://doi.org/10.1111/i.1478-3231.2011.02462.x PMID:21745271

33. Delgado-Andrade C. Carboxymethyl-lysine: thirty years of investigation in the field of AGE formation. Food Funct. 2016; 7:46-57. https://doi.org/10.1039/c5fo00918a PMID:26462729

34. An X, Zhang L, Yao Q, Li L, Wang B, Zhang J, He M, Zhang J. The receptor for advanced glycation endproducts mediates podocyte heparanase expression through NF-kB signaling pathway. Mol Cell Endocrinol. 2018; 470:14-25.

https://doi.org/10.1016/j.mce.2017.05.004

PMID:28478303

35. Wang Z, Bao Z, Ding Y, Xu S, Du R, Yan J, Li L, Sun Z, Shao C, Gu W. Ne-carboxymethyl-lysine-induced $\mathrm{PI3K} /$ Akt signaling inhibition promotes foam cell apoptosis and atherosclerosis progression. Biomed Pharmacother. 2019; 115:108880.

https://doi.org/10.1016/j.biopha.2019.108880 PMID:31035012

36. Huang SM, Hsu CL, Chuang $\mathrm{HC}$, Shih $\mathrm{PH}, \mathrm{Wu} \mathrm{CH}$, Yen GC. Inhibitory effect of vanillic acid on methylglyoxalmediated glycation in apoptotic Neuro-2A cells. Neurotoxicology. 2008; 29:1016-22.

https://doi.org/10.1016/j.neuro.2008.07.002 PMID:18706441

37. Müller TD, Finan B, Bloom SR, D’Alessio D, Drucker DJ, Flatt PR, Fritsche A, Gribble F, Grill HJ, Habener JF, Holst JJ, Langhans W, Meier JJ, et al. Glucagon-like peptide 1 (GLP-1). Mol Metab. 2019; 30:72-130. https://doi.org/10.1016/i.molmet.2019.09.010 PMID:31767182

38. Wang JL, Lin YC, Young $\mathrm{TH}$, Chen $\mathrm{MH}$. Far-infrared ray radiation promotes neurite outgrowth of neuron-like PC12 cells through AKT1 signaling. J Formos Med Assoc. 2019; 118:600-10.

https://doi.org/10.1016/j.jfma.2018.08.015

PMID:30173931

39. Kim YS, Gulfam M, Lowe TL. Thermoresponsive- coBiodegradable Linear-Dendritic Nanoparticles for Sustained Release of Nerve Growth Factor To Promote Neurite Outgrowth. Mol Pharm. 2018; 15:1467-75. https://doi.org/10.1021/acs.molpharmaceut.7b01044 PMID:29320631
40. Zhang H, Song B, He S. Interleukin 29 activates expression of tissue inhibitor of metalloproteinase 1 in macrophages via toll-like receptor 2. Mol Med Rep. 2018; 17:8363-68.

https://doi.org/10.3892/mmr.2018.8865

PMID:29658577

41. Yang Y, Ren J, Tong Y, Hu X, Lv Q, Tong N. Protective Role of PPARdelta in Lipoapoptosis of Pancreatic $\beta$ Cells. Lipids. 2016; 51:1259-68. https://doi.org/10.1007/s11745-016-4190-5 PMID:27631677

42. Jack CR Jr. Alzheimer disease: new concepts on its neurobiology and the clinical role imaging will play. Radiology. 2012; 263:344-61. https://doi.org/10.1148/radiol.12110433 PMID:22517954

43. Langbaum JB, Fleisher AS, Chen K, Ayutyanont $N$, Lopera F, Quiroz YT, Caselli RJ, Tariot PN, Reiman EM. Ushering in the study and treatment of preclinical Alzheimer disease. Nat Rev Neurol. 2013; 9:371-81. https://doi.org/10.1038/nrneurol.2013.107 PMID:23752908

44. Albert MS, DeKosky ST, Dickson D, Dubois B, Feldman $\mathrm{HH}$, Fox NC, Gamst A, Holtzman DM, Jagust WJ, Petersen RC, Snyder PJ, Carrillo MC, Thies B, Phelps CH. The diagnosis of mild cognitive impairment due to Alzheimer's disease: recommendations from the National Institute on Aging-Alzheimer's Association workgroups on diagnostic guidelines for Alzheimer's disease. Alzheimers Dement. 2011; 7:270-79.

https://doi.org/10.1016/j.jalz.2011.03.008 PMID:21514249

45. Stephan BC, Hunter S, Harris D, Llewellyn DJ, Siervo M, Matthews FE, Brayne C. The neuropathological profile of mild cognitive impairment (MCl): a systematic review. Mol Psychiatry. 2012; 17:1056-76.

https://doi.org/10.1038/mp.2011.147 PMID:22143004

46. McKhann GM, Knopman DS, Chertkow H, Hyman BT, Jack CR Jr, Kawas CH, Klunk WE, Koroshetz WJ, Manly JJ, Mayeux R, Mohs RC, Morris JC, Rossor MN, et al. The diagnosis of dementia due to Alzheimer's disease: recommendations from the National Institute on Aging-Alzheimer's Association workgroups on diagnostic guidelines for Alzheimer's disease. Alzheimers Dement. 2011; 7:263-69.

https://doi.org/10.1016/j.jalz.2011.03.005 PMID:21514250

47. Luchsinger JA, Reitz C, Patel B, Tang MX, Manly JJ, Mayeux R. Relation of diabetes to mild cognitive impairment. Arch Neurol. 2007; 64:570-75. https://doi.org/10.1001/archneur.64.4.570 PMID: $\underline{17420320}$ 
48. Li W, Wang T, Xiao S. Type 2 diabetes mellitus might be a risk factor for mild cognitive impairment progressing to Alzheimer's disease. Neuropsychiatr Dis Treat. 2016; 12:2489-95.

https://doi.org/10.2147/NDT.S111298

PMID:27729793

49. Vlassara H, Striker GE. Advanced glycation endproducts in diabetes and diabetic complications. Endocrinol Metab Clin North Am. 2013; 42:697-719.

https://doi.org/10.1016/i.ecl.2013.07.005

PMID:24286947

50. Mansur RB, Ahmed J, Cha DS, Woldeyohannes HO, Subramaniapillai M, Lovshin J, Lee JG, Lee JH, Brietzke $E$, Reininghaus EZ, Sim K, Vinberg M, Rasgon N, et al. Liraglutide promotes improvements in objective measures of cognitive dysfunction in individuals with mood disorders: A pilot, open-label study. J Affect Disord. 2017; 207:114-20.

https://doi.org/10.1016/i.jad.2016.09.056

PMID:27721184

51. Isacson R, Nielsen E, Dannaeus K, Bertilsson G, Patrone C, Zachrisson O, Wikström L. The glucagonlike peptide 1 receptor agonist exendin-4 improves reference memory performance and decreases immobility in the forced swim test. Eur J Pharmacol. 2011; 650:249-55.

https://doi.org/10.1016/i.ejphar.2010.10.008

PMID:20951130

52. Feng C, Li D, Chen $M$, Jiang L, Liu X, Li Q, Geng C, Sun X, Yang G, Zhang L, Yao X. Citreoviridin induces myocardial apoptosis through PPAR- $\gamma-m T O R C 2-$ mediated autophagic pathway and the protective effect of thiamine and selenium. Chem Biol Interact. 2019; 311:108795.

https://doi.org/10.1016/j.cbi.2019.108795

PMID:31419397

53. Kaur S, Nag A, Gangenahalli G, Sharma K. Peroxisome Proliferator Activated Receptor Gamma Sensitizes Non-small Cell Lung Carcinoma to Gamma Irradiation Induced Apoptosis. Front Genet. 2019; 10:554

https://doi.org/10.3389/fgene.2019.00554

PMID:31263479
54. Szczepańska AA, Łupicka M, Korzekwa AJ. Do arachidonic acid metabolites affect apoptosis in bovine endometrial cells with silenced PPAR genes? Prostaglandins Other Lipid Mediat. 2019; 143:106336. https://doi.org/10.1016/j.prostaglandins.2019.106336 PMID:31112752

55. Ma Y, Wang B, Li L, Wang F, Xia X. The administration of peroxisome proliferator-activated receptors $\alpha / \gamma$ agonist TZD18 inhibits cell growth and induces apoptosis in human gastric cancer cell lines. J Cancer Res Ther. 2019; 15:120-25.

https://doi.org/10.4103/0973-1482.208753

PMID:30880766

56. Zhang L, Gao J, Tang $P$, Chong L, Liu Y, Liu P, Zhang $X$, Chen L, Hou C. Nuciferine inhibits LPS-induced inflammatory response in BV2 cells by activating PPARv. Int Immunopharmacol. 2018; 63:9-13. https://doi.org/10.1016/i.intimp.2018.07.015 PMID:30056259

57. Wang ZJ, Zhang HB, Chen C, Huang H, Liang JX. Effect of PPARG on AGEs-induced AKT/MTOR signalingassociated human chondrocytes autophagy. Cell Biol Int. 2018; 42:841-48. https://doi.org/10.1002/cbin.10951 PMID:29453775

58. Hunter K, Hölscher C. Drugs developed to treat diabetes, liraglutide and lixisenatide, cross the blood brain barrier and enhance neurogenesis. BMC Neurosci. 2012; 13:33.

https://doi.org/10.1186/1471-2202-13-33 PMID:22443187

59. Kastin AJ, Akerstrom V. Entry of exendin-4 into brain is rapid but may be limited at high doses. Int J Obes Relat Metab Disord. 2003; 27:313-18. https://doi.org/10.1038/sj.ijo.0802206 PMID:12629557

60. Deacon $\mathrm{CF}$, Johnsen $\mathrm{AH}$, Holst JJ. Degradation of glucagon-like peptide-1 by human plasma in vitro yields an $\mathrm{N}$-terminally truncated peptide that is a major endogenous metabolite in vivo. J Clin Endocrinol Metab. 1995; 80:952-57. https://doi.org/10.1210/jcem.80.3.7883856 PMID: 


\section{Supplementary Figures}
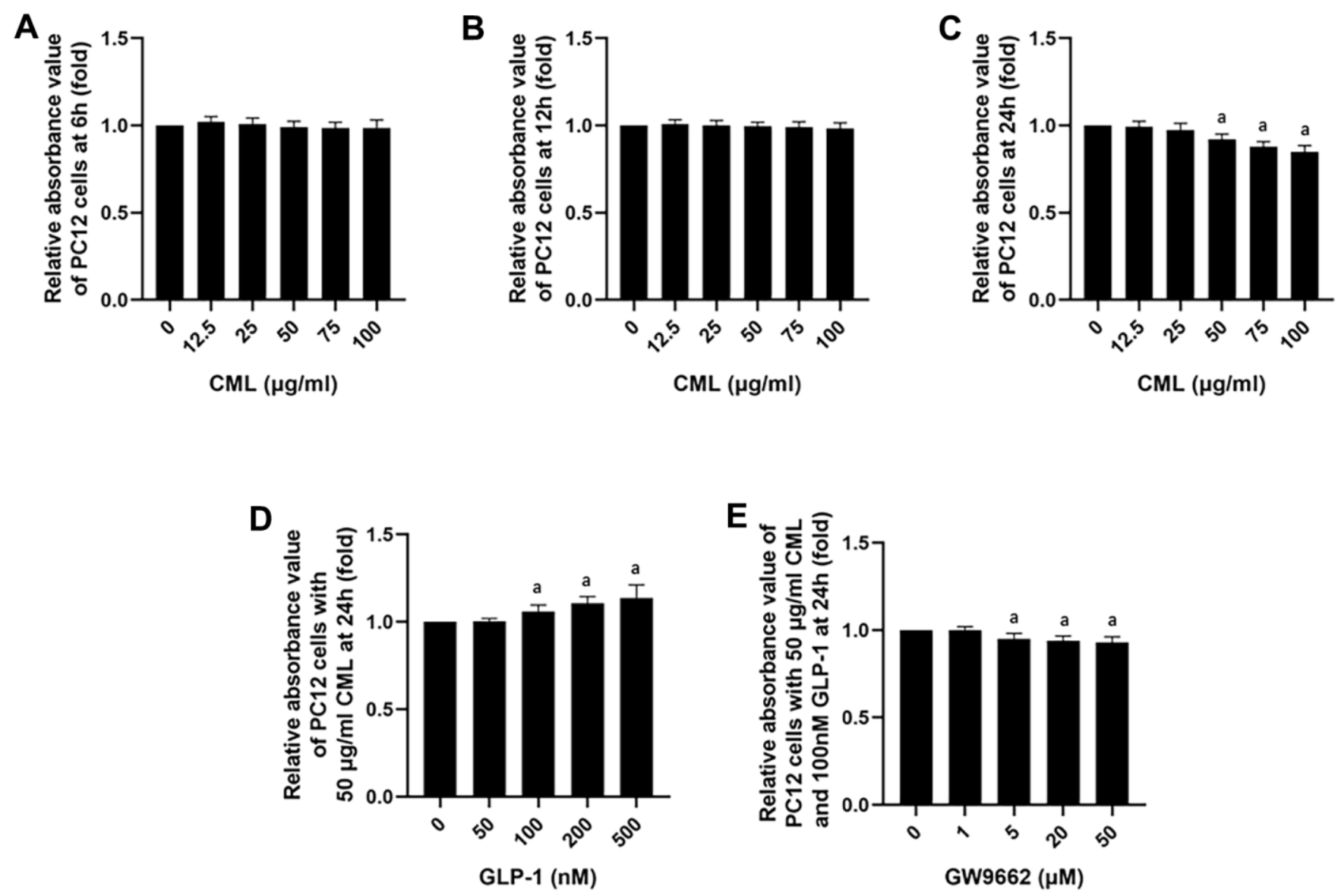

Supplementary Figure 1. PC12 cells viability with different treatments. Results showed in (A, B) did not show lower cells viability in PC12 cells with CML at than those without CML at $6 \mathrm{~h}$ or $12 \mathrm{~h}$. "a" in (C) showed decreased cells viability in PC12 cells with CML (50, 75, or 100 $\mu \mathrm{g} / \mathrm{ml}$ ) at $24 \mathrm{~h}$, compared those without CML (all P<0.05). "a" in (D) showed higher cells viability of PC12 cells with 100, 200, or 500 $\mathrm{nM} / \mathrm{ml}$ GLP-1 than those without GLP-1 (all P<0.05). "a" in (E) showed lower cells viability of PC12 cells (treated by $50 \mathrm{ug} / \mathrm{ml} \mathrm{CML} \mathrm{and} 100 \mathrm{nM}$ GLP-1) with 5, 10, 20, 50 uM GW9662 than those without GW9662 (all $P<0.05$ ). 
A

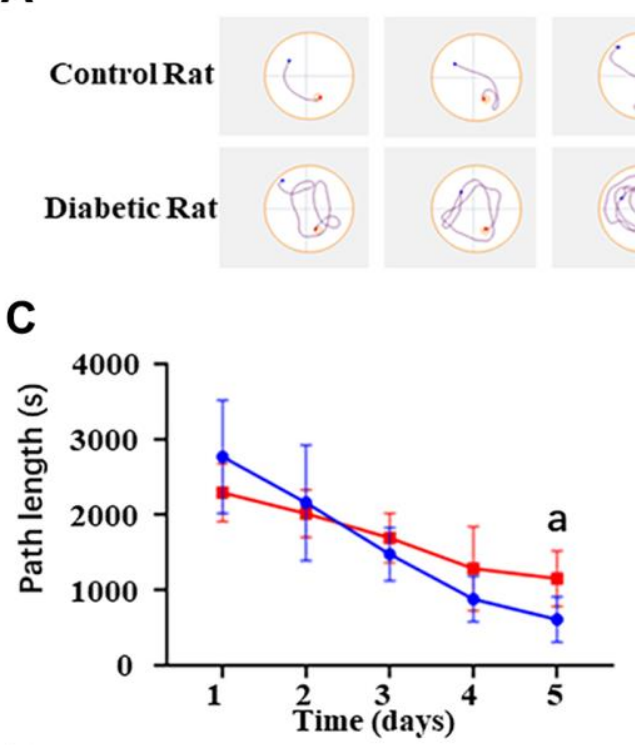

E

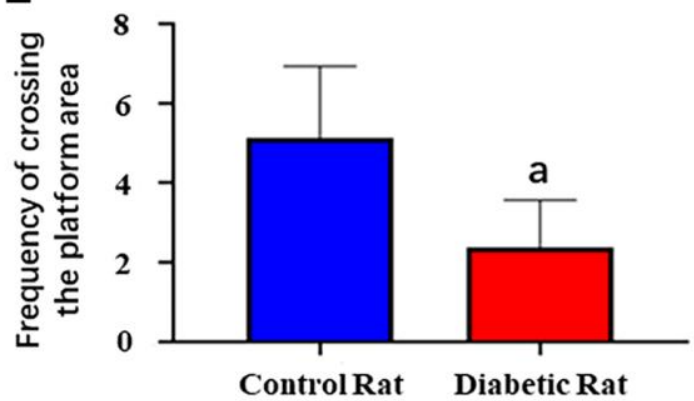

B

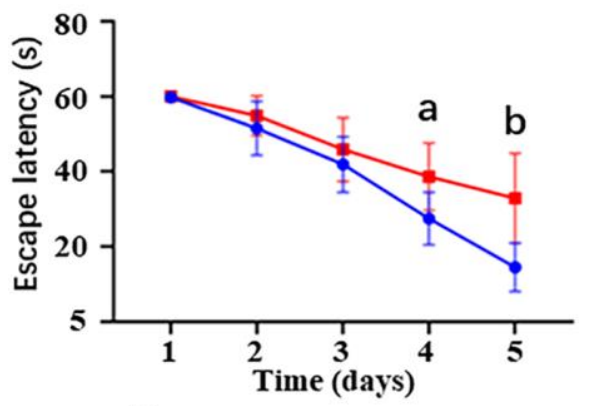

Control Rat

Diabetic Rat

D
Control Rat

Diabetic Rat

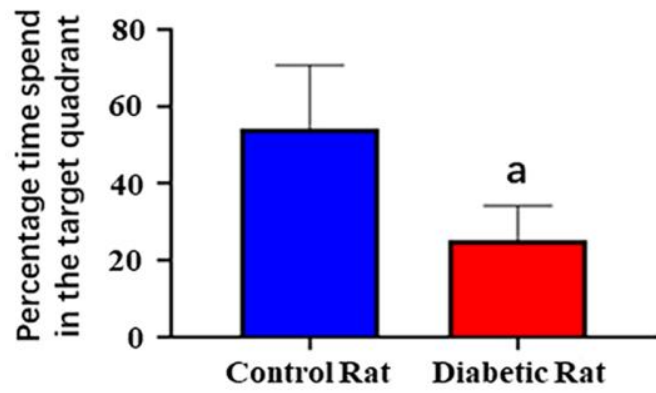

F

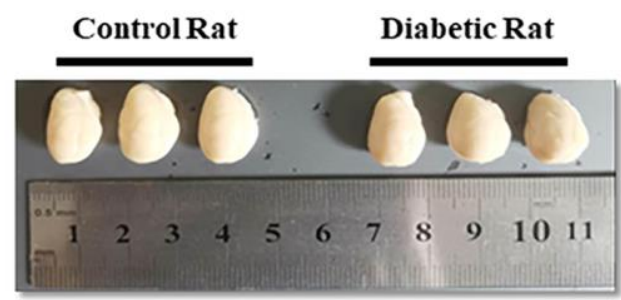

Supplementary Figure 2. Cognitive function was impaired in diabetic rats. In (A), we showed the swimming pathways of rats found the platform. "a" and " $b$ " of (B) showed different escape latency at the $4^{\text {th }}$ day and the $5^{\text {th }}$ day respectively. "a" of (C) showed different path length at the $5^{\text {th }}$ day. "a" of (D, E) showed different percentage of time spent in the target quadrant and frequency of crossing platform area between diabetic rats and control rats (all $P<0.05)$. In $(\mathbf{F})$, we did not find significant difference between brain sizes of diabetic rats and control rats. Data are represented as mean $\pm S D ; n=8$ per group for results of water maze. 